\title{
ANALISIS MARGIN PEMASARAN AYAM BROILER DI PASAR TRADISIONAL KOTA MANADO
}

(Study kasus di Pasar Bersehati Calaca dan Pinasungkulan Karombasan)

\author{
Yudianto Mandak, B. Rorimpandey*, P. O. V. Waleleng, F. N. S. Oroh
}

Fakultas Peternakan, Universitas Sam Ratulangi Manado

\begin{abstract}
ABSTRAK
Penelitian ini dilaksanakan di Pasar tradisional Kota Manado khususnya pasar Bersehati Calaca dan Pinasungkulan Karombasan. Masalah dalam penelitian yaitu bagaimana saluran pemasaran ayam broiler, apakah ada perbedaan jumlah margin pada masing masing saluran, serta apakah ada perbedaan tingkat efisiensi pemasaran ayam pada masing-masing saluran pemasaran. Tujuan penelitian yaitu (1) Untuk mengetahui bentuk saluran pemasaran ayam broiler di pasar tradisional Kota Manado, (2) Berapa besar Margin pemasaran dan keuntungan, (3) Berapa besar tingkat efisiensi pemasaran pada masing masing saluran pemasaran ayam broiler di pasar tradisional Kota Manado. Sumber data yakni data primer dan data sekunder. Penentuan sampel dilakukan secara purposive sampling, berdasarkan pertimbangan pedagang tetap yang sudah beraktivitas lebih dari 3 tahun. Model analisis data menggunakan pendekatan analisis deskriptif yaitu untuk mengkaji bentuk pemasaran ayam broiler dan analisis matematis untuk mengetahui jumlah margi, keuntungan dan efisiensi pemasaran. Hasil penelitian diperoleh bahwa rata - rata harga beli ayam broiler pada pedagang pengumpul adalah sebesar Rp. 19.500 per kilogram dengan rata - rata harga jual sebesar Rp 27.000 per kilogram
\end{abstract}

*Korespondensi (corresponding Author) Email: rorimpandeyboyke@ymail.com dan rata - rata total biaya pemasaran adalah sebesar Rp. 3.903. Sedangkan rata - rata harga beli ayam broiler pada pedagang pengecer adalah sebesar Rp. 26.182 per kilogram dengan rata - rata harga jual sebesar Rp 29.364 per kilogram dan rata - rata total biaya pemasaran adalah sebesar Rp. 1.789. Kesimpulan yaitu : pasar bersehati dan pinasungkulan memiliki dua saluran pemasaran yakni ; (1), Peternak ke pedagang pengumpul ke pedagang pengecer ke konsumen. (2), Peternak ke pedagang pengumpul ke konsumen. Jumlah margin dan keuntungan yang diperoleh berbeda pada tiap saluran, pada saluran pertama sebesar Rp 9.864 dan pada saluran dua jumlah margin yang diperoleh sebesar $\quad \mathrm{Rp} 7.500$ Sedangkan keuntungan yang diperoleh dari saluran I yaitu sebesar Rp. 4.172 dan pada saluran II mendapatkan keuntungan sebesar Rp. 3.597. Saluran pemasaran ayam broiler sudah berlangsung secara efisien karena tingkat efisiensi pada kedua saluran pemasaran tersebut berada antara $0-33 \%$ yaitu saluran I sebesar $19,39 \%$ dan saluran II sebesar $14,45 \%$.

Kata Kunci : Saluran Pemasaran, Margin, Keuntungan, Efisiensi Pemasaran, Ayam Broiler

\section{ABSTRACT}

MARGIN ANALYSIS OF BROILER
MARKETING AT TRADITIONAL
MARKETS IN MANADO CITY


(Case Study at Calaca Bersehati and Pinasungkulan Karombasan Markets)

This research was conducted at the traditional markets in Manado particularly at the Bersehati Calaca and Pinasungkulan Karombasan markets. The problem of this research was that how was the chains of broiler marketing channels, how much was margin profit of broiler marketing and level of broiler marketing efficiency at the traditional markets of Calaca Bersehati and Pinasungkulan Karombasan. The purposes of this study were (1) To determine the chain of broiler marketing channels at traditional markets in Manado, (2) marketing margins and profit, (3) To determine the level of marketing efficiency at each marketing channel of broiler chicken at the traditional market in Manado. Sources of data in this study were divided in the primary data and secondary data. The samples were taken by purposive sampling. Models of data analysis in this research were using descriptive analysis approach and mathematical analysis. The result showed that the average - average purchase price of broiler chickens on traders is IDR. 19,500 per kilogram with the average the average selling price of IDR 27,000 per kilogram and the average - average total marketing cost is Rp. 3903. While the average - average purchase price of broiler chickens on retailers is IDR. 26 182 per kilogram with the average - the average selling price of $\operatorname{Rp} 29,364$ per kilogram and the average - average total marketing cost is IDR. 1789.

Conclusion that the markets at Calaca Bersehati and Pinasungkulan Karombasan had two marketing channels as follows (1), Farmers to traders, traders to retailers, and retailers to consumers. (2), Farmers to traders, traders to consumers. Total margin and gains different on each channel, the first channel of IDR 9.864 and on line two the margin obtained at IDR 7,500, while the benefits of the channel I is IDR. 4172 and the second channel a profit of IDR 3597. Broiler chicken marketing channels already take place efficiently because the level of efficiency in both marketing channels are located between 0-33 percents which amounted the first line was 19.39 percents and a second channel was 14.45 percents

Keywords: Marketing Channel, Margin, Profit, Marketing Efficiency, Broiler.

\section{PENDAHULUAN}

Pemasaran ialah suatu proses sosial baik individu maupun kelompok, yang terlibat dalam proses tersebut memperoleh apa yang mereka butuhkan dan inginkan dengan cara menciptakan, menawarkan, dan mempertukarkan produk atau jasa yang bernilai dengan pihak lain. Biaya pemasaran ialah seluruh biaya yang dikeluarkan oleh lembaga pemasaran berkaitan dengan pelaksanaan fungsi pemasaran. Funsifungsi pemasaran yang dimaksud diantaranya adalah bagian pengumpulan, penyimpanan dan pengangkutan. Biaya pemasaran juga didalamnya termasuk waktu kerja, resiko, kerusakan, kredit dan pemeliharaan informasi (Soekartawi, 2007).

Menurut Majid (2008), pasar tradisional adalah tempat pembeli dan 
penjual melakukkan transaksi secara langsung dan disertai dengan proses tawar menawar. Barang yang diperjualbelikan merupakan barang kebutuhan sehari-hari masyarakat, seperti makanan, kue, buh-buahan, pakaian, barang elektronik, dan jasa. Ayam Broiler dikenal masyarakat dengan berbagai kelebihannya, yaitu umur panen 5-8 minggu. Waktu pemeliharaan yang relatif singkat dan menguntungkan, maka banyak peternak baru serta peternak musiman yang bermunculan diberbagai wilayah Sulawesi Utara. Khususnya di Kota Manado Populasi ayam broiler meningkat, tercatat dalam data Badan Pusat Statistik Sulawesi Utara populasi ayam broiler selama 4 tahun terakhir terus meningkat yaitu di tahun 2012 sebanyak 61.546, tahun 2014 sebanyak 65.500, dan di tahun 2015 mencapai 104.000 ekor. Tercatat dalam data BPS Sulut 2016 pasar tradisional di Kota Manado terdapat enam Pasar yakni di kecamatan Malalayang (Pasar 66 Bahu), Wanea (Pasar Pinasungkulan), Wenang (Pasar Bersehati Calaca), Tuminting (Pasar Tuminting), Tikala (Pasar Orde Baru Paal 2), dan Kecamatan Bunaken (Pasar Bunaken).
Produksi ayam broiler yang meningkat disertai pertambahan jumlah penduduk akan menciptakan peluang usaha di bidang pemasaran, dimana sistem distribusi ayam broiler melibatkan beberapa lembaga pemasaran seperti pedagang besar, pedagang pengumpul, dan pedagang pengecer. Namun sebagian besar pedagang ayam broiler di pasar tradisional Kota Manado belum mengetahui bentuk saluran pemasaran ayam broiler yang ada, dan pedagang beranggapan bahwa setiap lembaga pemasaran ayam broiler memperoleh jumlah margin dan keuntungan yang besar, namun hal itu tergantung dari volume penjualan, harga jual, dan jumlah lembaga pemasaran yang terlibat dalam penyaluran ayam broiler.

Menanggapi permasalahan tersebut maka perlu dilakukan kajian mengenai aspek pemasaran komoditi ayam broiler. Hal-hal penting mengenai pemasaran ayam broiler adalah bentuk saluran pemarasan, nilai margin pemasaran, keuntungan dan efisiensi pemasaran. Berdasarkan uraian tersebut penulis mengambil judul "Analisis Margin Pemasaran Ayam Broiler di Pasar Tradisional Kota Manado". Tujuan Penelitian ini yaitu (1) Untuk 
mengetahui bentuk saluran pemasaran ayam broiler di pasar tradisional Kota Manado, (2) Berapa besar margin pemasaran dan keuntungan dari masingmasing saluran pemasaran ayam broiler di pasar tradisional Kota Manado, dan (3) Berapa besar tingkat efisiensi pemasaran pada masing masing saluran pemasaran ayam broiler di pasar tradisional Kota Manado.

\section{METODE PENELITIAN}

Penelitian dilaksanakan di pasar tradisional Kota Manado, khususnya pasar tradisional Bersehati Calaca dan pasar tradisional Pinasungkulan Karombasan mulai tanggal 13 Juni 2016 sampai 20 Juli 2016. Untuk memperoleh data dilakukkan melalui suatu proses penentuan sampel. Penentuan pasar dan responden pada penelitian dilakukkan berdasarkan purposive sampling (Singarimbun dan Efendi, 1995) dan (La Ode 2014). Penentuan pasar, purposive sampling dilakukkan terhadap pasar yang lebih banyak menjual ayam broiler. Penentuan responden, purposive sampling dilakukan atas dasar petimbangan bahwa pedagang tetap yakni sudah beraktivitas lebih dari 3 tahun dan secara intensitas melakukkan aktivitas di pasar bersehati dan pinasungkulan setiap hari.

Analisis data menggunakan analisis deskriptif dan matematis. Analisis deskriptif dimaksudkan untuk menguraikan secara kualitatif keadaan ril mata rantai pemasaran ayam broiler dan menguraikan aktivitas pedagang ayam broiler dalam bentuk bagan, tabel maupun persentese. Analisis matematis yaitu :

1. Margin pemasaran akan dihitung dengan rumus Menurut (Sudiyono, 2004) dan (Rais, 2013)

$$
\mathrm{Mp}=\mathrm{Hk}-\mathrm{Hp}
$$

Keterangan :

$\mathrm{Mp}=$ margin pemasaran $(\mathrm{Rp})$

$\mathrm{Hk}=$ Harga jualayam broiler $(\mathrm{Rp})$

$\mathrm{Hp}=$ Harga beli ayam broiler $(\mathrm{Rp})$

2. Keuntungan yang diperoleh masing-masing lembaga pemasaran, digunakan rumus (Thalib, 2013), dan (Siti Hajar, 2016).

$$
\Pi=\mathrm{M}-\mathrm{Bp}
$$

Keterangan :

$\Pi=$ Keuntungan Lembaga Pemasaran

$\mathrm{M}=$ Margin Pemasaran

Bp = Biaya Penjualan

3. Tingkat efisiensi pemasaran pada masing-masing saluran pemasaran, 
digunakan rumus (Rosmawati, 2011), dan (Siti Hajar, 2016)

$$
\text { Eps }=\frac{B}{H E} \times 100 \%
$$

Keterangan :

$$
\begin{array}{ll}
\mathrm{Eps} & =\text { Efisiensi Pemasaran } \\
\mathrm{Bp} & =\text { Biaya Pemasaran } \\
\mathrm{HE} & =\text { Harga Eceran }
\end{array}
$$

Dengan asumsi :
a. $0-33 \%=$ Efisien
b. $34-67 \%=$ Kurang Efisien
c. $68-100 \%=$ Tidak Efisien

\section{HASIL DAN PEMBAHASAN}

1. Saluran Pemasaran

Lembaga pemasaran yang terlibat dalam pemasaran ayam broiler di Pasar Bersehati Calaca dan Pinasungkulan Karombasan yaitu produsen (peternak), pedagang pengumpul, pedagang pengecer, konsumen akhir. Saluran pemasaran yang ada di pasar Bersehati dan Pinasungkulan terdapat dua saluran, dapat dilihat pada gambar 1 dan 2 .

Saluran I terdiri dari peternak, pedagang pengumpul, pedagang

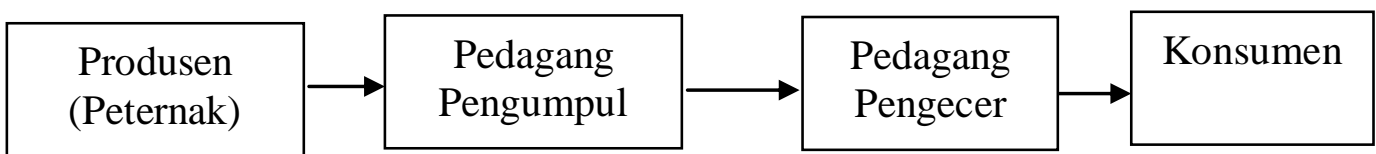

Gambar 1. Saluran Pemasaran Ayam Broiler di Pasar Bersehati dan Pinasungkulan pada saluran I

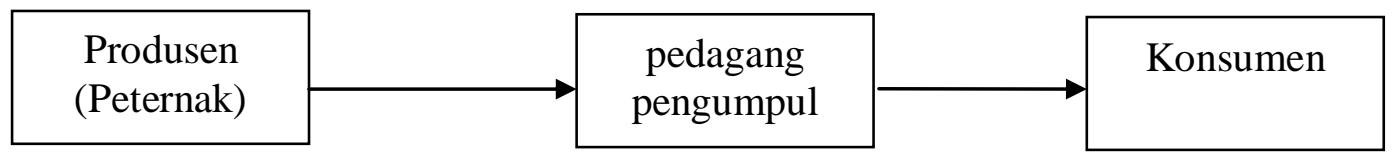

Gambar 2. Saluran Pemasaran Ayam Broiler di Pasar Bersehati dan Pinasungkulan pada saluran II pengecer, dan konsumen. Sistem pemasaran pada saluran ini tidak langsung karena peternak menjual ayam broiler ke pedagang pengumpul dengan cara pedagang pengumpul datang langsung ke peternak ayam broiler dan ada juga pedagang pengumpul menyetorkan uang di rekening peternak, yang nantinya selesai penyetoran ayam broiler akan di antar langsung oleh peternak ke tempat pedagang terjadi pada pedagang pengumpul dan peternak yang sudah lama bertransaksi jual beli ayam broiler atau bisa dikatakan pedagang pengumpul sudah berlangganan pada peternak tersebut. Pada saluran II terdiri dari peternak, pedagang pengumpul, dan Konsumen. Sistem pemasaran pada saluran ini yaitu pedagang pengecer membeli ayam broiler pada pedagang pengumpul langsung di pasar, ayam yang dibeli sudah dalam keadaan bersih dari bulu dan jeroannya. pengumpul. Sistem pembelian ini 
2. Margin Pemasaran

Margin merupakan perbedaan harga atau selisih harga yang dibayar konsumen akhir dengan harga yang diterima oleh peternak. Dalam hal ini margin pemasaran pedagang pengumpul adalah perbedaan harga yang dibayarkan kepada peternak dengan harga jual kepada pedagang pengecer, dan konsumen dalam saluran pemasaran dengan komoditi yang sama (Ali, 2014).

a. Margin Pemasaran Saluran I (Peternak, Pedagang Pengumpu, Pedagang Pengecer, Konsumen) Komponen biaya dan margin pemasaran pada saluran I dapat dilihat pada Tabel 1.

Tabel 1. Margin Pemasaran Ayam Broiler di Pasar Berseati dan Pinasungkulan

\begin{tabular}{|c|c|c|}
\hline \multirow{2}{*}{ Lembaga Pemasaran } & \multirow{2}{*}{ Variabel } & \multirow{2}{*}{$\begin{array}{c}\text { Saluran I } \\
\text { Nilai }(\mathrm{Rp} / \mathrm{Kg})\end{array}$} \\
\hline & & \\
\hline Peternak & Harga Jual & 19.500 \\
\hline \multirow[t]{5}{*}{ Pedagang pengumpul } & Harga Beli & 19.500 \\
\hline & Biaya Pemasaran & 3.903 \\
\hline & Keuntungan & 3.597 \\
\hline & Margin & 7500 \\
\hline & Harga Jual & 27.000 \\
\hline \multirow[t]{5}{*}{ Pedagang Pengecer } & Harga Beli & 27.000 \\
\hline & Biaya Pemasaran & 1.789 \\
\hline & Keuntungan & 1.393 \\
\hline & Margin & 2.364 \\
\hline & Harga Jual & 29.364 \\
\hline \multirow[t]{3}{*}{ Konsumen Akhir } & Harga Pembelian & 29.364 \\
\hline & Total Biaya Pemasaran & 5.692 \\
\hline & Total Margin & 9.864 \\
\hline
\end{tabular}


Total margin sebesar Rp 9.864 per kilogram, total biaya pemasaran sebesar Rp 5.692 per kilogram. Biaya pemasaran pedagang pengumpul adalah sebesar Rp 3.903, masing - masing terdiri dari biaya tenaga kerja sebesar Rp 3.472 per kilogram, biaya transportasi sebesar Rp 451,4,- per kilogram, biaya retribusi sebesar Rp 57,7 per kilogram dan biaya pengemasan sebesar $\mathrm{Rp}$ 22,3 per kilogram. Sedangkan biaya pemasaran pemasaran pedagang pengecer sebesar Rp 1.789, masing - masing terdiri dari biaya transportasi sebesar Rp 1500 per kilogram, biaya retribusi sebesar
Rp 208, dan biaya pengemasan sebesar Rp 80,9.

b. Margin Pemasaran Saluran II (Peternak,Pedagang Pengumpul, Konsumen)

Komponen biaya dan margin pemasaran pada saluran II dapat dilihat pada Tabel 2. Total margin sebesar Rp 7500 per kilogram. Biaya pemasaran pedagang pengumpul adalah sebesar Rp 3.903, masing - masing terdiri dari biaya tenaga kerja sebesar Rp 3.472 per kilogram, biaya transportasi sebesar Rp 451,4,- per kilogram, biaya retribusi sebesar Rp 57,7 per kilogram dan biaya pengemasan Rp 22,3 per kilogram.

Tabel 2. Margin Pemasaran Ayam Broiler di Pasar Berseati Calaca dan Pinasungkulan Karombasan Pada Saluran II

\begin{tabular}{llc}
\hline \multirow{2}{*}{ Lembaga Pemasaran } & Variabel & Saluran II \\
\cline { 3 - 3 } Peternak & Harga Jual & Nilai (Rp/Kg) \\
\cline { 2 - 2 } pedagang pengumpul & Harga Beli & 19.500 \\
& Biaya Pemasaran & 19.500 \\
& Keuntungan & 3.903 \\
& Margin & 3.597 \\
& Harga Jual & 7500 \\
Konsumen Akhir & Harga Pembelian & 27.000 \\
& Total Biaya Pemasaran & 27.000 \\
& Total Margin & 3.903 \\
& & 7500 \\
\hline
\end{tabular}


Jumlah margin yang diperoleh pada saluran II lebih kecil daibandingkan pada saluran I. Hal ini dikarenakan saluran kedua hanya menggunakkan satu lembaga pemasaran dan biaya pemasarannya pun sedikit. Hal ini didukung pendapat Jumiati (2013) dan Duungan (2014) yang menyatakan bahwa semakin panjang jarak dan semakin banyak perantara yang terlibat dalam pemasaran, maka biaya pemasaran semakin tinggi dan margin pemasaran juga semakin besar.

2. Keuntungan Pemasaran

Keuntungan Pemasaran ayam broiler di pasar tradisional kota manado dapat dilihat pada Tabel 3. Pada tabel dibawah menunjukkan bahwa keuntungan pada saluran I dengan menggunakan dua lembaga pemasaran yaitu pedagang pengumpul memperoleh keuntungan sebesar Rp. 3.597 per kilogram dan pedagang pengecer memperoleh keuntungan sebesar $\mathrm{Rp}$ 574 per kilogram. Jumlah keuntungan yang diperoleh pada saluran I sebesar Rp 4.172 Per kilogram. Jumlah keuntungan padaa saluran II dengan hanya menggunakan satu lembaga pemasaran yaitu pedagang pengecer memperoleh keuntungan sebesar $\mathrm{Rp}$ 3.597 per kilogram. Artinya semakin panjang saluran pemasaran maka keuntungan yang diterima peternak semakin kecil.

\section{Tingkat Efisiensi Pemasaran}

Tingkat efisiensi pemasaran ayam broiler di Pasar Bersehati dan Pinasungkulan pada saluran I dan saluran II dapat dilihat pada Tabel 4. Pada Tabel 4 menunjukkan bahwa pada saluran 1 jumlah total efisiensi pemasaran yang di peroleh adalah sebesar 19,39\% dan pada saluran II sebesar 14,45 .

Tabel 3. Keuntungan Lembaga Pemasaran Ayam Broiler Setiap Saluran Pemasaran di Pasar Bersehati Calaca dan Pinasungkulan Karombasan

\begin{tabular}{lcc}
\hline \multirow{2}{*}{ Lembaga Pemasaran } & \multicolumn{2}{c}{ Keuntungan $(\mathrm{Rp} / \mathrm{Kg})$} \\
\cline { 2 - 3 } & Saluran I & Saluran II \\
\hline Pedagang pengumpul & 3.597 & 3.597 \\
Pedagang Pengecer & 574 & - \\
Jumlah & 4.172 & 3.597 \\
\hline
\end{tabular}


Tabel 4. Efisiensi pemasaran Ayam Broiler di Pasar Bersehati dan Pinasungkulan

\begin{tabular}{lccc}
\hline \multirow{2}{*}{ Lembaga Pemasaran } & \multicolumn{3}{c}{ Efisiensi Pemasaran (\%) } \\
\cline { 2 - 4 } & Saluran 1 & Saluran 2 & Keterangan \\
\hline Pedagang Pengumpul & 13,29 & 14,45 & Efisien \\
Pedagang Pengecer & 6,09 & - & Efisien \\
Jumlah & 19,39 & 14,45 & Efisien \\
\hline
\end{tabular}

Tabel 4 menunjukkan bahwa saluran pemasaran I dan II efisien, hal ini didukung oleh Rosmawati (2011) bahwa jika nilai 0-33\% dikategorikan efisien, jika nilai 34-67\% dikategorikan kurang efisien, dan jika nilai 68-100\% dikategorikan tidak efisien.

\section{KESIMPULAN}

1. Terdapat dua saluran pemasaran ayam broiler di Pasar Tradisional Kota Manado, khususnya Pasar Bersehati Calaca dan Pinasungkulan Karombasan yaitu : Saluran I peternak $\rightarrow$ pedagang pengumpul $\rightarrow$ pedagang pengecer $\rightarrow$ konsumen, dan saluran II peternak $\rightarrow$ pedagang pengumpul $\rightarrow$ konsumen,

2. Jumlah margin dan keuntungan yang diperoleh berbeda pada tiap saluran pemasaran yang ada yakni saluran I margin yang diperoleh sebesar Rp 9.864 dan pada saluran II jumlah margin yang di peroleh sebesar Rp 7500,-. Sedangkan keuntungan yang diperoleh dari saluran I yaitu sebesar Rp. 4.172 dan pada saluran II mendapatkan keuntungan sebesar Rp. 3.597,

3. Tingkat efisiensi saluran pemasaran ayam broiler di pasar tradisional Kota Manado sudah berlangsung secara efisien karena tingkat efisiensi pada kedua saluran pemasaran tersebut berada antara 0$33 \%$ yaitu saluran I sebesar $19,39 \%$ dan saluran II sebesar $14,45 \%$.

\section{DAFTAR PUSTAKA}

Ali I. 2014. Analisis margin pemasaran ternak sapi bali di Kecamatan Pulubala Kabupaten Gorontalo. Jurnal KIM Fakultas Ilmu-Ilmu Pertanian. Vol 2 (2) : 93-111

Badan Pusat Statistik. 2016. Sulut Dalam Angka. BPS-SULUT. Manado

Duungan, I. N. A. 2014. Analisis efisiensi pemasaran sapi bali di Kabupaten Bangli, E-Jurnal, 
Journal Of Tropical Animal Science, Vol. 2 (3) : 338-350

Jumiati, E. 2013. Analisis saluran pemasaran dan marjin pemasaran kelapa di daerah perbatasan Kalimantan Timur. Jurnal AGRIFOR. Vol 11 (1) : 1-10

La. Ode S. 2014. Potensi agribisnis usaha ternak ayam broiler di kota kendari. Jitro Vol. 1 (1).: 88-98

Majid, A. 2008. Pengertian, Konsep dan Definisi Pemasaran. http:// majid. wordpress.com/ 2008/ 06/ 30/ pengertian konsep definisi pemasaran. Posted on 30 Juni 2008. Diakses Tanggal 27 Februari 2016.

Rais, F, 2013. Beef marketing efficiency in Gorontalo City. Jurnal KIM Fakultas Ilmu-Ilmu Pertanian, Vol. 1 (1) : 1-10

Rosmawati, H. 2011. Analisis efisiensi pemasaran pisang produksi petani di kecamatan lengkiti Kabupaten Ogan Komering Ulu . Jurnal Agronobis. Vol. 3 (5) : 1-9

Sudiyono, A. 2004. Pemasaran Pertanian. Malang, UMM Press.

Singarimbun., M dan Effendi S. 1995. Metode Penelitian Survey. Lembaga Penelitian, Pendidikan dan Penerangan Ekonomi dan Sosial. Jakarta.

Siti H. D. 2016. The study of marketing channel and efficiency of sentul chicken (a case study of farmers group in barokah abadi farm Kabupaten Ciamis). Jurnal Universitas Padjajaran. Vol 5 (2) : 14-30
Soekartawi, 2007 Ilmu Usaha Tani dan Usaha Kecil. UI Press. Jakarta

Thalib, F. 2013. Analisis margin pemasaran ayam pedaging di Kota Utara Kota Gorontalo, Jurnal KIM Fakultas Ilmu-Ilmu Pertanian. Vol. 1(1) :1-9. 